

K.Okamura del. 


\title{
New or Little Known Algae from Japan.
}

By

\author{
K. Okamura, Rigakuhakushi.
}

\author{
With Pl. IX.
}

In December 23,1893, I wrote to the late Prof. Fr. Schmitz sending him some specimens of the following plants together with their descriptions and illustrations, and asking his judgment on my determination. They are Cryptonemia angusta, Cryp. Wilsoni?, and Polyopes Polyideoides. They were considered by me to be new and he agreed with me, but not without some different views. He promised me to publish them in Hedwigia, under the title "Neue japanische Florideen von $\mathrm{K}$. OKamura mitgetheilt von Fr. Schmitz." But this promise was interfered with by his lamented death. On receiving the news of his death, I took up again the subject, and after a closer study of those algae, I am now about to publish these results of my investigations.

\section{Grateloupia divaricata sp. nov. Fig. 1-2.}

Frond narrow-linear, compressed cartilaginous, irregularly divaricato-dichotomous, with \pm long stipe, tapering to both apex and base, beset with marginal horizontal, distichous, irregnlarly inserted longer or shorter, simple or forked proliferous ramuli which are constricted at base. Tetraspores collected in the median and terminal portion of proliferations and in terminal segments. Cystocarps here and there scattered in a small group in last and last but one or two segments, and also in proliferations.

Hab. On rocks between tide marks; Noto, Wakasa, Idzumo.

Fronds, numerous from a common callous dise, each rising with a single stem, from $7-15 \mathrm{~cm}$ ligh, rarely $30 \mathrm{~cm}$ or more, narrowed at its base, soon becoming compressed and afterwards preserving everywhere a nearly equal width of 1-1.5 $\mathrm{mm}$ till, approaching to the apices, 
it again grows narrower, and ends in a sharpish point as it began. Stem is undivided at the base for a more or less long distances, then becomes divaricately dichotomous, the distance between the lower dichotomies being longer than that between the upper ones. Sometimes the ramification is more regularly dichotomous in somewhat flabellate manner, but more usually it is irregular, irregularities being assisted by divaricately decompound segments and by large secondary branches, which have developed from proliferations, either simply elongating or similarly dichotomo-decompounded as other portion of frond. In some specimens, segments expand somewhat beneath the forks, being slightly canaliculated. All the branches are beset on both sides (rarely from surface) with proliferous ramuli, usually $1-2 \mathrm{~cm}$ long, distichous, scattered, some standing nearer to each other in secund manner, others rather remote; some remain simple and short, others forked. Proliferations are linear constricted at base, tapering at apex. Terminal segments often elongate.

Fruits of both kinds are formed in ultimate segments and proliferous ramuli. Tetraspores forming a subsorus in the median or terminal portion of ramuli, oblong, immersed among cortical filaments. Cystocarps here and there scatterel in a few groups in terminal portion of frond and in proliferations. They are not found in older and luwer segments.

Color dull purplish-green, becoming greenish-yellow. Substance cartilaginous, becoming firmer in drying. Plants do not adhere to paper in drying.

The present plant which may be referred to the section chondrophyllum distributed by Prof. J. Agardh, and may be placed in the vicinity of Grateloupia dichotoma, Gr. spathulata and Gr. Cosentinii. The many times dichotomous frond of the present plant induces us to think of its relation with $G r$. dichotoma, to which it seems to me to be most closely related; but the more regularly dichotomo-fastigiate, small sized habit of the latter differs from the more divaricate and large size of the present. Moreover, I remember the substance to have been thinner in Gr. dichotoma, a fragmental specimen of which I have seen in the herbarium of the Imperial University in Tokio. Grat. spathulata, on the contrary, differs from the present by its larger size, its broader segments, and its terminal spathulate lacineae. Girat. 
Cosentinii differs chiefly in its more gelatinous substance and the position of Cystocarps. From Grat. Affinis and var. carnosa Okamura (Bot. Mag. Tokio Vol. VII. No. 75 p. 100 and 101 Pl. V. fig. 3-10), one of the members belonging to this section, it so greatly differs in habit, that there is no need to enter into a minute demonstration.

With Grat: filicina, on the other hand, the present alga shows some relations; for, there is, in some specimens, a very close resemblance in appearance between the two species. In such specimens, the frond is very much elongated and remain for a greater length simple; then once or twice forks at longer distances, and the segments from the base to apical portion are beset on both sides with proliferous very elongated, simple or once distantly forked horizontal, distichous branches, either naked or clothed with lesser sorts of ramuli. One may easily take such forms for Grat. filicina, though dichotomous ramification is rarer in case in that species. The substance, however, is firmer and more cartilaginous than Grat. filicina, and moreover, even in those specimens, tetraspores are collected in proliferous younger branches not in older segments, while in Grat. filicina, tetrispores and cystocarps are equally scattered over the frond.

Thus I doubt, on the one hand, whether the present plant may not be a dichotomous and more cartilaginous variety of Grat. filicina, if I am not mistaken in referring such forms to this species. On the other hand, the present alga seems to me to be an intermediate form between Grat. filicina and the section to which Grat. dichotoma etc. belong.

The alga is distributed in a narrow range, having been abundantly collected in Noto, Wakasa and Idzumo, which are provinces along the coast of the Japan Sea, and hitherto has not been brought from the Pacific side.

\section{Polyopes Polyideoides sp. nov. Fig. 3-7.}

Fronds numerous from the same base, firmly cartilaginous, subterete below, somewhat compressed and thickened above, ending in a blunt apex, subfastigiato-dichotomous, dichotomies being closer above, more usually irregularly dichotomous, with patent roundish axils, slightly narrowed here and there, mostly at forks, more or less beset with horizontal simple or forked marginal proliferous ramuli, similar in shape 
and substance to segments. Fruits of both kinds collected in an oblong group on both surfaces of ultimate segments.

Hab. On rocks between tide marks; Sagami, Suruga. Tōtōmi, Shima, Tosa.

Fronds numerous rising from an expanded callous disc, $5-15 \mathrm{~cm}$ high, cylindrical at base, slightly compressed above, 1-2 mm broad, and are fastigiato-dichotomous, dichotomies being more closer above. Segments are linear-cuneate, almost cylindrical, here and there very slightly constricted, patent, ending in blunt apex or bifid. Proliferations arise both from margin and from harmed apex. They are simple, almost horizontal, constricted at base; at first minute and glandulose, but afterwards elongate and assume the shape similar to other segments of frond.

Cystocarps are collected in terminal segments, which are often somewhat separated from lower portion by constriction. They form an oblong subnematheciose aggregation on both surfaces, opening afterward by a carpostom; nucleus lodged in a cavity beneath the cortical layer, simple, globutar, surrounded by the circumnuclear filaments, at the base of which a placental cell is situated, from which radiates a mass of spores.

Tetraspores also form an oblong sorus on both surfaces of ultimate segments leaving marginal portion sterile; they are oblong, cruciate, immersed among the cortical filaments.

Frond consists of two layers of cells; the inner, of densely interwoven longitudinal anastomosing filaments; in a longitudinal section, filaments are seen to anastomose forming a net-work with elongated meshes, which become gradually shorten outward, the length of meshes almost equalizing their breadth; the outer, of vertical moniliform dichotomous filaments strongly bound together by mucilage.

Substance is carnoso-cartilaginous when recent, almost corneous in drying. Color dark purplish-red, fading to yellowish.

The present plant has a habit very similar to that of Polyides lumbricalis, from which, however, it differs in many respects. It seems to me so closely resembled Polyopes constrictus that I took my plants for that species, since I relied upon its description, without seeing any specimens of it. On sending my plant under that name to the late Prof. Fr. Schmitz, asking him his opinion of my identification, I was 
favoured with the following reply: "Die Pflanze, die Sie mir als Poly. constrictus sandten, genau zu bestimmen, ist mir aber noch nicht gelungen; mit $P$. constrictus vom Cap. b. Sp. ist diese Pflanze augenscheinlich nicht identisch, doch scheint sie derselben Gattung anzugehören." The difference of the present plant from that typical plant seems to consist in its more flattish and more frequent constrictions at "mostly shortish intervals" (Turn. Fuci IfI p. 40). From other species of Polyopes which have been transferred from the species of Cryptonemia by J. Agardh (Till Alg. Syst. IV. p. 17), i.e. Poly. ligulata, P. rigida, $P$. Phyllophora, $P$. decipiens and $P$. elata, my plant seems to be much more different than it is from $P$. constrictus. Thus I venture to establish. the present plant as a new species under the specific name Polyideoides, on the supposition of its resemblance to Polyides lumbricalis.

3. Cryptonesuia angusta (Harv.) 0kam. Fig. 8-15.

syn. Gymnogongrus ligulatus var. angustus

Harv. Cha. of New Alg. no. 29.

Frond rigid cartilaginous,. compressed or sometimes thickened in the median line and two-headed, divaricately decomposito-dichotomous. Segments linear or linear-cuneate, here and there constricted, ending in blunt, bifid or ligulate apex, pinnately seriated along the margin with proliferations which form roundish phyllae in fructified frond, or grow up into branches, similar to other segments. Fruits of both kinds collected in marginal proliferations or beneath the apex of terminal segments.

Hab. On rocks in deev tide. Bōshū, Sagami, Idzu, Tōtōmi, Shima.

Fronds, numerous rising from a broad basal disc, the basal portion is often almost cylindrical in older specimens, more flattened and compressed above 10-30 $\mathrm{cm}$ high. The ramification is divaricately dichotomous, often tri-polychotomous with widely patent, recurved and entangled segments which have rounded patent axils. Segments are compressed and linear being 15-2 $\mathrm{mm}$ bivad or cuneate beneath forks in upper portion; in some more widened into $5 \mathrm{~mm}$ or more in breadth and often thickening in the median line like a costa. Terminal seg- 
ments in some are linear as in lower portion, ending in blunt or bifid apex or slightly broadened or much more expanded with round apex. Margin is in some specimens subaequal throughout, but more frequently is constricted at different distances. Proliferations arise from orlandular elevation along margin, also from terminal portion and more usually from harmed ends. Lateral proliferations usually remain short and roundish in fructified frond, but often elongate into more or less long branches which are more frequently the case in those issuing from the terminal portion.

Fruits of both kinds collected in marginal proliferations in a nematheciose manner. Cystocarps are collected beneath the flattish surface of marginal roundish proliferated sporophylls; they are also found forming a roundish nemathecia beneath the apex of marginal and terminal elongated proliferations and sometimes in the similar position of terminal non-proliferous segments. Tetraspores are aggregated forming an intramarginal sorus in lateral roundish proliferations, whose margin remain sterile and is elevated into a thick rim.

The structure of the frond is very dense; the medullary layer consists of densely aggregated shortish filamentous cells firmly united to each other by hyaline intercellular substance; the intermediate cells are of roundish angular cells which become gradually smaller above, forming a cortical layer. In the sporophyll bearing tetraspores the structure is little different; there is no evident intermediate cell and medually layer is more loose, from which moniliform filaments arise, among which oblong tetraspores are lodged.

Color is deep blood-red, becoming dirker in drying. Substance is strongly cartilaginous becoming very stiff when dried.

The present plant has been formerly described by Prof. Harvey under the name of Gymnogongrus ligulatus $v$. angustus in his Cha. of New Algae No. 29. His Gym. ligulatus from Ceylon has been referred to the genus Cryptonemia by Prof. J. Agardh (Epicr. p. 162) who, again, transferred it in the genus Polyopes (J. Ag. Till Alg. Syst. IV p. 17), on account of the nemathcciose aggregation of cystocarps in terminal segments.

I sent the present plant together with other two species to the late Prof. Fr. Schmitz under the name of Cryptonemia ligulata $v$. angusta (Harv.) Okam. to ask his judgement on my determination. 
In answer to my question he wrote: "Ihre Crypt. lig. v. angusta habe ich mit den Original-Pflanzen Harvey's verglichen und habe dabei erkannt, dass Thre Alge in der 'That mit der Harvey'schen Pflanze aus Japan identisch ist, von der Harvey'schen Pflanze aus Ceylon aber specifisch getrennt werden muss." From these lines I ascertained that my determination was not mistaken and my plant is not the same with Crypt. ligulata Harv. from Ceylon.

Of the systematic position of the present plant I am in doubt, whether it should be placed in Crystonemia or in Polyopes. According to Prof. J. Agardh's view (Till Alg. Syst. IV p. 17) the nematheciose collection of cystocarps in terminal segments separates Polyopes from Cryptonemia. Now, in my plant cystocarps are mostly aggregated in lateral proliferations which are short and roundish, and are also formed like a nemathecia below the apex of lateral elongated proliferations. They are again found below the apex of terminal non-proliferous segments, though not frequent in case. Thus my plants seem to me to stand in an intermediate position between Polyopes and Cryptonemia. But owing to the prevalence of the presence of cystocarps in lateral proliferous segments, I think that it is more proper to place the present plant in the genus Cryptonemia.

Next, I took the structure of frond into consideration. In Cryptonemia the frond is composed of three strata, there being an intermediate stratum of roundish cells between cortical minute cells and medullary filamentous layer. In Polyopes, I doubt the presence of intermediate cells. On comparing it with my Polyopes Polyideoides I find that the present species has an intermediate layer, while in the former there is none. And in J. Agardh's Till Alg. Syst. I.c., the author says: "in plurimis (Polyopis) stratum intermediam vix adest, in nonnullis (Poly. phyllophora Harv.) almodum evolutum conspiciatur." On the other hand, the late Prof. Fr. Schmitz established Polyopes phyllophora Harv. in a new genus Carpopeltis (Schm. syst. übersich. und bisher bekannt. Gatt. und Florid. p. 19). I do not know on what character he established this species in that new genus, as I have no reference but the above cited; but I venture to suppose that he would perhaps do so on the character of intermediate large angular cells; for it seems to me on its other characters it must be considered as a species of Polyopes. I regret that in my collection I have no specimen of Cryptonemia but a very small fragment of Crypt. lomation. I took 
the structure of that fragment in comparison and I found that there is intermediate cells, though the medullary layer is more loose than in the present plant. From the point of view of the structure of frond, also, I venture to suppose that it is more proper to place the present species in the genus Cryptonemia.

So far is my reason on placiug the present plant in the genus Cryptonemia. I can say nothing about the relations of the present plant with other species of Cryptonemia, as I have no specimen of that genus to compare with.

\section{Cryptonemia Wilsonı J. Ag. ? Fig 16-22.}

Frond membranous, rosy-red, leaflike, without midrib, with a stem, rarely simple and broadly lanceolate, usually expanding into broadly linear cuneate rachis, from whose margin and surface (rather rarely) similarly leafy simple or once-forked pedicellate lanceolate proliferations arise in a pinnate manner. Fruits of both kind collected in a small oblong or roundish sporophyll densely arising from the surface and margin. Cystocarps lodged in a cavity beneath the cortex of thick fleshy sporophyll. Tetraspores forming a dense sorus in more flattish sporophyll.

Hab. Perhaps on rocks in deep tide. Bōshū, Sagami, Shima.

Root a scutate disc. Frond, when quite simple, is a simple lanceolate leaf furnished with a short cylindrical stem, destitute of midrib, often attaining the height of ca $25 \mathrm{~cm}$ by $4 \mathrm{~cm}$; more usually, however, it assumes a linear cuneate form, with simple or branched stipe, loaded with proliferations from the margin and surface. The frond then often attains the height of $40 \mathrm{~cm}$ or more, and the breadth of rachis is usually $2-3 \mathrm{~cm}$. Proliferations (also arising abundantly from harmed ends) are lanceolate or cuneato-lanceolate, simple or once forked with patent axils furnished with their own pedicels, mostly ending in an acute point, or rarely in a blunt apex, often wasting off at upper portion, attaining the length of some $22 \mathrm{~cm}$ by $1-5 \mathrm{~cm}$. Younger proliferations are naked, but in older, again loaded with smaller sorts of proliferations. Margin entire when newly formed, lacerated when old.

Cystocarps are collected in a minute fleshy oblong sporophyll, 
about $1.5 \mathrm{~mm}$ long; nucleus simple, globular, Todged in a cavity beneath cortex. Tetraspores forming a dense sorus in a similar but thinner sporophylls, situated among moniliform cortical filaments of the both surfaces, oblong, cruciate.

The structure of frond is dense, consisting of three layers of cells; the medullary, of densely interwoven short filaments; the intermediate, of a few-layers of large roundish cells, often elongating tangentially; the cortical, of vertically seriated subcubic cells, arranged not in dichotomous filaments. The cells of intermediate and medullary layer are filled with highly refractible substance. The structure of a sporophyll differs from that of the sterile portion of frond; the filamentous layer is more loosely constructed, and the cortical layer is composed of vertical dichotomous moniliform filaments in tetrasporic sporophyll, while in cystocarpic ones, the structure of cortical layer is the same as in other portion, the intermediate cells being smaller. In an old specimen I found small dot like protuberances densely scattered all over the surface of frond. I took them, at first, for the younger formation of tetrasporic sori; but, afterwards, on examining fully formed sporophylls, I came to the conclusion that they were in fact the beginning of sporophylls.

Color is rosy-red when young, becoming darker in age. Substance is pergamenous in younger portion, more cartilaginous in older, and the plant does not adhere to paper in drying.

Formerly I considered the present plant to be a new species of Cryptonemia, taking into account the structure of frond and the characters of sporophyll, but not without a doubt on the difference of habit. So I sent it to the late Prof. Fr. Schmitz under the name Cryptonemia lanceolata to ask him of my determination. In reply, he wrote to me: "Ihre Crypt. lanceolata ist augenscheinlich eine ganz neue Art. Ich zweifele jedoch, ob diese Art zu Cryptonemia zu stellen ist oder in eine ganz neue Gattung." He wrote to me so, bat he did not tell me on what character it should be established in a new genus. On receiving his answer, I entered into more close examination of my plant; but I could not find any difference so important as to be established in a new genus, except the difference of habit and the presence of sporophylls on the surface. (It seems to me that sporophylls in the species of Cryptonemia are mostly proliferated from margin, though $I$ have seen 
no specimen of the species of this genus). On examining the structure of nucleus I found that there is, connected with surrounding filamentous plexus, a basal placental cell, on which rests a subcylindrical granular cell, from which a globular mass of spores are radiated. Each spore is enclosed with a colorless perispore, which is also the case in Crypto. angusta. 'The presence of this granular cell I thought to be a characteristic point distinguishing the present plant from the genus Cryptonemia. On examining the nucleus of C'ryptonemia angusta for comparison, (as I have no specimen of Cryptonemia, as I have stated in other pages) I found the structure of nucleus to be similar. Otherwise, I could not find any distinguishing character in this plant. If I an to consider the present plant as a new genus, I must take the difference of habit and the presence of sporophylls from the surface of frond into account. But such secondary characters seem to me to be insufficient to establish a new genus.

In the course of my study I found a new species of Cryptonemia established by Prof. J. Agardh, i.e. Crypt. Wilsoni. (J. Ag. Till Alg. Syst. Vol. IV p. 25). It seems strongly to resemble my plant, so much so that I am inclined to consider whether it is not identical with my plants. Its veinless large-sized frond, pinnated by marginal linearlancenlate proliferations, its color and structure induces me to identify my plant with his species. His plant was not furnished with no fruits, but he mentions the presence of dot like protuberances-" Fronds adultiores nunc maculis punctiformibus sparsis instructas vidi; at frustra fructus indicia certa quaesivi." (J. Ag. l.c. p. 26). Those dot-like protuberances, I suppose to be the beginning of sporophylls, as I' met with the similar case in my plant. If this supposition of mine proves to be correct, the sporophylls will be found over the frond in his plant.

Thus at first I considered this plant as a new species of Cryptonemia, and in the next place I inclined to establish it in a new genus ander the name Schmitzia; but lastly, on comparing my plant with the description of Crypt. Wilsoni J. Ag., I came to incline to identify the present plint with his species. But as I have not seen his plant, I marked iny plant with (?). If my plant afterwards proves to be not identical with it, I shall propose a new specific name Schmitziana.

Botanical Laboratory of the Fourth Higher School, Kanazawa, Japan, Oct. 12, 1895. 


\section{Explanation of Figures in Plate IX.}

\section{Grateloupia divaricata sp. nov.}

Fig. 1. A smaller form bearing tetraspores; nat. size.

Fig. 2. A smaller form bearing cystocarps; nat. size.

2. Polyopes Polyideoides sp. nov.

Fig. 3. A portion of sterile frond; nat. size.

"4. A portion of the longitudinal section of frond ; $\frac{240}{2}$.

" 5. A terminal portion with tetrasporic sori; nat. size.

" 6. A cross-section through the tetrasporic sorus; $\frac{240}{1}$.

" 7. A terminal portion with cystocarps; nat. size.

\section{Cryptonemia angusta (Harv.) Okam.}

Fig. 8. A portion of frond bearing cystocarps; nat. size.

" 9. A cross-section of frond ; $\frac{240}{1}$.

"10. A cross-section of a tetrasporic ramulus; slightly $\times{ }^{d}$.

"11. Portion of the same; $\frac{240}{1}$.

"12. A cross-section of a ramulus bearing cystocarps; slightly $x^{d}$.

" 13. A cystocarp, some of spores remòved; $\frac{85}{1}$.

„14. A Placental cell; $\frac{2,00}{1}$.

$"$ 15. A spore; $\frac{2 \pm 0}{1}$.

\section{Cryptonemia Wilsoni J. Ag. ?}

Fig. 16a. A frond bearing tetrasporic sporophylls; $\frac{1}{3}$.

„16b. Other forms of frond; nat. size.

$"$ 17. A small piece of the cross-section of frond; $\frac{2,0}{1}$.

" 18. A sporophyll bearing tetraspores, with its cross section; slightly $\times{ }^{d}$.

19. Cortical layer of the same; $\frac{240}{2}$.

"20. Longitudinal section through a sporophyll with cystocarps; slightly $x^{\mathrm{d}}$.

„21. A mass of spore radiating from a placental cell; $\frac{28}{2}$.

"22. Placental cells. $\frac{240}{2}$. 